\title{
Physiological Quality of Pigeonpea Seed after Application of Desiccant Herbicides
}

\author{
Raniele Tadeu Guimarães', Itamar Rosa Teixeira ${ }^{1 *}$, André José Campos1, \\ Gisele Carneiro da Silva1, Ivano Alessandro Devilla1, Alessandro Guerra da Silva², \\ Paulo César Timossi ${ }^{3}$ \\ ${ }^{1}$ Department of Agricultural Engineering, Sate University of Goiás, Anápolís, Brazil \\ ${ }^{2}$ Department of Agricultural, University of Rio Verde, Rio Verde, Brazil \\ ${ }^{3}$ Department of Agricultural, Federal University of Goiás, Jataí, Brazil \\ Email: ${ }^{*}$ itamar.texeira@ueg.br
}

Received 20 January 2015; accepted 6 April 2015; published 10 April 2015

Copyright (C) 2015 by authors and Scientific Research Publishing Inc.

This work is licensed under the Creative Commons Attribution International License (CC BY). http://creativecommons.org/licenses/by/4.0/

(c) (i) Open Access

\section{Abstract}

The pre-harvest application of herbicides may impair seed quality. This way, this paper was conducted to evaluate the effects of the application of desiccant herbicides on the physiological quality of pigeonpea seeds. Six batches of seeds from plants desiccated with glyphosate were evaluated

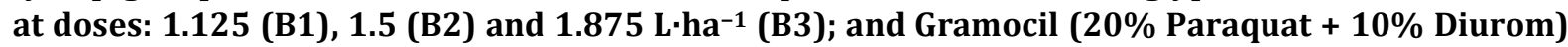
at doses: 1.5 (B4) and $2 \mathrm{~L}^{\cdot h a^{-1}}$ (B5), and a control which received no application (B6). Seed viability was assessed through the germination standard test, and vigor through the first germination count, accelerated aging, electrical conductivity, seedling length, seedling dry matter and biomass density tests. The experimental design was the completely randomized, with four replications. Data were submitted to variance analysis, and when significant effects were observed, the ScottKnott test was carried out at $5 \%$ probability using the SISVAR 5.1 software. The results showed that: a) the application of $1.875 \mathrm{~L} \cdot \mathrm{ha}^{-1}$ of glyphosate was harmful to pigeonpea seed viability and vigor, evaluated through the accelerated aging test; b) applications of glyphosate in a $1.875 \mathrm{~L}^{\cdot h \mathrm{~h}^{-1}}$ dose and Gramocil in $2 \mathrm{~L} \cdot \mathrm{ha}^{-1}$ resulted in low vigor according to the electrical conductivity test of seeds; and c) the seed vigor measured by the first count, seedling length, seedling dry matter and biomass density test was not influenced by the type of desiccant applied.

\section{Keywords}

Cajanus cajan (L.) Millsp., Pre-Harvest Desiccation, Deterioration, Maturity, Vigor

\footnotetext{
${ }^{*}$ Corresponding author.
}

How to cite this paper: Guimarães, R.T., Teixeira, I.R., Campos, A.J., da Silva, G.C., Devilla, I.A., da Silva, A.G. and Timossi, P.C. (2015) Physiological Quality of Pigeonpea Seed after Application of Desiccant Herbicides. American Journal of Plant Sciences, 6, 826-832. http://dx.doi.org/10.4236/ajps.2015.66089 


\section{Introduction}

The Cajanus cajan species is one of the most important grains, ranking fifth in importance among edible food legumes, showing good protein production under low soil fertility and low rainfall conditions [1], standing out as a source of human food and fodder, being one of the most used for green fertilization (manure-based), and for having the ability to fix nitrogen up to $135 \mathrm{~kg} \cdot \mathrm{ha}^{-1}$ [2]. There is an average worldwide annual production of 3.43 million tons in an area of 4,640,000 ha in tropics and subtropics regions of the world [3].

The bean grain is rich in starch, protein, calcium, manganese, crude fiber, lipids and minerals. In addition to its high nutritional value, the pigeonpea is also used as traditional popular medicine in India, China, the Philippines and other countries [4]. Its proteins have hiugh concentration of lysine, allowing its use as a complement to cereal proteins.

The cultivars suitable for grain production are within the pigeon var. flavus (DC.) group, which includes small plants, early seed production, yellow flowers and green pods with two to three seeds [5]. In seed production, pigeonpea is characterized by uneven ripening of the pods, harvest being recommended when the plants present a good percentage of mature pods [6]. This way, the first ripe pods have longer exposure to climatic variations and unripe pods are harvested with a high humidity percentage.

The main problems observed in seed production are related to deterioration caused by humidity and those originating from integumentary injuries [7], as a result of expansion and contraction caused by wetting and drying cycles, which increases frailty, reduces seed protection and impairs its development [8]. According to literature, if the harvest is accomplished late, natural degradation, grain breaking in the track system and great losses can occur if this period coincides with the rainy season [9]. Therefore, technologies that enable both uniform and early harvesting become essential for seed production. It is important to mention the alternative use of preharvest desiccants, a practice aimed mostly at anticipating and planning the harvest, reducing weeds and ensuring high quality of the harvested product [10].

Several results have been obtained with the use of desiccants in terms of reducing humidity levels and preserving seed quality in various crops: [11] noted that the carfentrazone-ethyl herbicide impaired the quality of bean seeds after 80 days of storage; [12], while studying bean drying with glufosinate ammonium, also found negative effects on the quality of produced seeds; [13], found that the pre-harvest drying of soybean plant seeds with glyphosate caused a reduction in seed germination and in initial seedling development.

As to pigeonpea, studies addressing the influence of desiccant herbicides on seed production are still scarce. That being said, the objective of this study was to evaluate the influence of desiccant herbicides on the physiological quality of pigeonpea seeds.

\section{Material and Methods}

\subsection{General Information}

The seeds used in this study came from the pigeonpea seed production of IAPAR-43 cultivar (Aratã), early maturing, suitable for human and animal consumption, produced in the 2012/2013 harvest, at the EMATER-GO experimental unit, Anápolis, GO, Brazil, 48¹8'23"W longitude and 16¹9'44"S latitude, at 1.017-m-high. The climate, according to Köppen classification, is the type AW tropical humid, characterized by dry winter and rainy summer, with average annual rainfall between 1200 and $1800 \mathrm{~mm}$, and temperatures ranging from $20^{\circ} \mathrm{C}$ to $30^{\circ} \mathrm{C}$.

Samples of soil classified as dystrophic red-yellow latosol in the 0 - $20 \mathrm{~cm}$ layer were collected and chemical-physical analysis, with the following results: $\mathrm{pH}\left(\mathrm{H}_{2} \mathrm{O}\right)-6.4 ; \mathrm{P}$ (Mehlich)—-5.6 mg. $\mathrm{kg}^{-1}$; $\mathrm{K}$ (Mehlich)—0.72 $\mathrm{mg} \cdot \mathrm{kg}^{-1} ; \mathrm{Ca}+\mathrm{Mg}-2.3 \mathrm{cmol}_{\mathrm{c}} \cdot \mathrm{kg}^{-1} ; \mathrm{H}+\mathrm{Al}-2.6 \mathrm{cmol}_{\mathrm{c}} \cdot \mathrm{kg}^{-1} ; \mathrm{V}-64 \%$; organic matter-23.4 g. $\mathrm{dm}^{-3}$; $\mathrm{sand}^{225}$ $\mathrm{g} \cdot \mathrm{kg}^{-1}$; silt $163 \mathrm{~g} \cdot \mathrm{kg}^{-1}$ and clay $612 \mathrm{~g} \cdot \mathrm{kg}^{-1}$.

The main features of IAPAR-43 (Aratã) are: erect shrub growth, cycle 90 to 120 days, height of 1.0 to $1.5 \mathrm{~m}$, 100 to $180 \mathrm{~kg} / \mathrm{ha}$ of N, 20 to $30 \mathrm{ton}$./ha of green mass and thousand seed weight of 70 to $75 \mathrm{~g}$.

\subsection{Experimental Design and Treatments}

During the pre-harvest, the seed batches used in the study were defined according to the applied doses of the following desiccant herbicides: Paraquat (200 g. $\mathrm{L}^{-1}$ of active ingredient 1,1'-dimetil-4,4'-bipiridilio dicloreto, íon) + Diurom (100 g· $\mathrm{L}^{-1}$ of active ingredient 3-(3,4-diclorofenil)-1,1-dimetil uréia)—GRAMOCIL ${ }^{\circledR}$ (trade- 
mark); and Glyphosate (360 $\mathrm{g} \cdot \mathrm{L}^{-1}$ of active ingredient equivalent acid $\mathrm{N}$-fodfonometil glycine)—ROUNDUP ${ }^{\circledR}$ (trademark). Table 1 lists the applied doses and the batch identifications.

\subsection{Trait Measurements}

The evaluation of the physiological quality of the pigeonpea seeds was carried out through the following tests:

Standard Germination Test (SGT): consisted of four replications with 50 seeds distributed onto two sheets of germitest paper covered by a third sheet, previously wetted at a 2.5 by 1 ratio $(\mathrm{mL}$ of distilled water by the dry paper weight in grams). Then, rolls were made with the sheets of paper containing the seeds and placed in a sprouting chamber at a controlled temperature of $25^{\circ} \mathrm{C} \pm 1{ }^{\circ} \mathrm{C}$. On the tenth day the rolls were opened for percentage counting of normal seedlings according to the Seed Testing Rules (STR) [14].

Germination first count (FC): was performed along with SGT on the fourth day after the test setup, recording the percentage of normal seedlings obtained and evaluating their vigor [14].

Accelerated Aging $(A A)$ : gerboxes $(11 \times 11 \times 3 \mathrm{~cm})$ were used containing $40 \mathrm{~mL}$ of distilled water and $42 \mathrm{~g}$ of pigeonpea seeds distributed in a single uniform layer onto the screen that isolates them from water. The capped boxes were placed in a BOD chamber at $41^{\circ} \mathrm{C} \pm 1^{\circ} \mathrm{C}$ for 48 hours [15] After this period the SGT was carried out through four replications with 50 seeds, according to the procedures described in the STR [14]. On the fourth day, the normal seedlings were counted.

Electrical conductivity $(E C)$ : in order to evaluate the strength of the pigeonpea seeds through the electrical conductivity test, four replications were carried out with 50 seeds that were weighed at a $0.01 \mathrm{~g}$ precision and soaked in $200 \mathrm{~mL}$ plastic cups containing $75 \mathrm{~mL}$ of deionized water for 24 hours at $25^{\circ} \mathrm{C} \pm 1^{\circ} \mathrm{C}$ [16]. Next, the conductivity was read with a DIGIMED CD-21 conductivimeter, and the results expressed in $\mu \mathrm{S} \cdot \mathrm{cm}^{-1} \cdot \mathrm{g}^{-1}$ of seed.

Seedling length $(S L)$ : in order to measure vigor through the length test, the procedures described by [16] were applied. Four replications with 10 pigeonpea seeds were accomplished. A lengthwise line was drawn in the top third part of the germitest paper. The sheets of paper were previously moistened to the same ratio described in the SGT. The rolls were prepared and placed vertically in the sprouting chamber for four days at $25^{\circ} \mathrm{C} \pm 1^{\circ} \mathrm{C}$. After that period, the normal sprouted seedlings were rule-measured. The average seedling length values were expressed in centimeters.

Seedling dry mass (DM): After obtaining the seedling lengths, cotyledons were removed and hypocotyls were separated from rootlets. The hypocotyls and radicles were placed in separate paper bags, which were kept in a greenhouse under the temperature of $80^{\circ} \mathrm{C} \pm 3^{\circ} \mathrm{C} 24 \mathrm{~h}^{-1}$. At the end of this period the seedlings dry mass weight was recorded in $\mathrm{mg}$. The results were expressed in average weight, that is, the dry mass weight divided by the number of seedlings placed in the paper bag for drying [16].

Biomass density $(B D)$ : additionally, the dry biomass weight per seedling centimeter, that is, the biomass density was evaluated. In order to obtain the values of this variable, expressed in milligrams per seedling centimeter $\left(\mathrm{mg} \cdot \mathrm{cm}^{-1}\right)$, the equation 1 was used. This value was obtained from mass and length measurements of each seedling in the batch [17]:

$$
\mathrm{DB}=\mathrm{DM} / \mathrm{SL}
$$

where:

Table 1. Description of the doses applied in the desiccation of the pigeonpea seed batches.

\begin{tabular}{ccc}
\hline Herbicide & L·ha ${ }^{-1}$ (p.c. & Batch \\
\hline Gramocil $^{\circledR}$ & 1.5 & B1 \\
Gramocil $^{\circledR}$ & 02 & B2 \\
Roundup $^{\circledR}$ & 1.25 & B3 \\
Roundup $^{\circledR}$ & 1.5 & B4 \\
Roundup $^{\circledR}$ & 1.875 & B5 \\
No application & 00 & B6 \\
\hline
\end{tabular}


DB: biomass density.

DM: seedling dry mass.

SL: seedling total length.

\subsection{Data Analysis}

The data obtained were submitted to variance analysis and "F" test, and the values derived from the SGT, 1st germination count and accelerated aging were transformed into sin arc $\sqrt{(\mathrm{x} / 100)}$, since they are percentage values. In cases where the "F" test produced significant results at $5 \%$ probability, the Scott-Knott test was carried out also at $5 \%$ of significance. Analyses were carried out using SISVAR 5.1 software [18].

\section{Results and Discussion}

After completion of the variance analysis of the average values derived from the Standard Germination Test (SGT), First Count (FC), Accelerated Aging (AA), Electrical Conductivity (EC), Seedling Length (SL), Dry Mass (DM) and Biomass Density (BD), it was observed that the desiccant applied had significant influence on SGT, AA, and EC values (Table 2).

Table 3 presents the SGT, FC, AA, EC, SL, DM and BD average values according to the desiccant applied. The lowest percentage of germinated seedlings (76.5\%) is observed with B5 (Round Up-1.875 L·ha ${ }^{-1}$ ) compared to the other applications and the non-application of desiccant. The same is observed by [19], in testing with application of desiccants at different times in the pea crop, when it was noticed that by the time of the first and second application the smallest germination values were obtained when glyphosate was used in any of the doses used. [12] observed that paraquat and paraquat + diuron do not affect germination in any application time for the bean crop, supporting the findings of this study. Paraquat is a contact herbicide that acts directly on the plant photosynthetic system, causing significant toxicity and tissue death shortly after application [20], so the

Table 2. Calculated F and Variation Coefficient values of the variance analysis (ANOVA) of six batches of pigeonpea seeds subjected to different doses of desiccant herbicides.

\begin{tabular}{|c|c|c|c|c|c|c|c|}
\hline \multirow{2}{*}{$\mathrm{FV}$} & \multicolumn{7}{|c|}{ Calculated F } \\
\hline & SGT & FC & AA & EC & SL & $\mathrm{DM}$ & $\mathrm{BD}$ \\
\hline Treatments & $5.237^{*}$ & $2.616^{\text {ns }}$ & $5.693^{*}$ & $2.821^{*}$ & $1.581^{\mathrm{ns}}$ & $0.487^{\mathrm{ns}}$ & $5.455^{\mathrm{ns}}$ \\
\hline VC (\%) & 7.18 & 8.93 & 6.69 & 16.19 & 10.61 & 11.24 & 11.58 \\
\hline
\end{tabular}

${ }^{*}$ Significant and non-significant ${ }^{n s}$ at 5\% error probability. SGT—Standard germination test; FC—First count; AA—Accelerated aging; EC—Electrical conductivity; SL—Seedling length; DM—Dry mass and BD—Biomass density.

Table 3. Average values of these tests for the application of desiccants doses or not in pigeon pea seeds.

\begin{tabular}{cccccccc}
\hline \multirow{2}{*}{ Evaluated variables } & \multicolumn{7}{c}{ Treatment } \\
\cline { 2 - 7 } & B6 & B3 & B4 & B5 & B1 & B2 \\
\hline SGT (\%) & $96.0 \mathrm{~A}$ & $93.0 \mathrm{~A}$ & $92.0 \mathrm{~A}$ & $76.5 \mathrm{~B}$ & $93.0 \mathrm{~A}$ & $89.5 \mathrm{~A}$ \\
FC (\%) & $81.5 \mathrm{~A}$ & $80.5 \mathrm{~A}$ & $87.5 \mathrm{~A}$ & $68.0 \mathrm{~A}$ & $79.5 \mathrm{~A}$ & $85.0 \mathrm{~A}$ \\
AA $(\%)$ & $87.5 \mathrm{~A}$ & $88.5 \mathrm{~A}$ & $78.0 \mathrm{~B}$ & $69.5 \mathrm{C}$ & $80.5 \mathrm{~A}$ & $84.0 \mathrm{~A}$ \\
EC $\left(\mu \mathrm{S} \cdot \mathrm{cm}^{-1} \cdot \mathrm{g}^{-1}\right)$ & $53.2 \mathrm{~B}$ & $53.9 \mathrm{~B}$ & $55.42 \mathrm{~B}$ & $72.7 \mathrm{~A}$ & $53.6 \mathrm{~B}$ & $64.6 \mathrm{~A}$ \\
$\mathrm{SL}(\mathrm{cm})$ & $8.2 \mathrm{~A}$ & $7.8 \mathrm{~A}$ & $9.3 \mathrm{~A}$ & $7.8 \mathrm{~A}$ & $8.3 \mathrm{~A}$ & $8.5 \mathrm{~A}$ \\
$\mathrm{DM}\left(\mathrm{mg} \cdot \mathrm{plant}^{-1}\right)$ & $7.8 \mathrm{~A}$ & $7.1 \mathrm{~A}$ & $7.9 \mathrm{~A}$ & $7.5 \mathrm{~A}$ & $7.5 \mathrm{~A}$ & $7.5 \mathrm{~A}$ \\
$\mathrm{BD}\left(\mathrm{mg} \cdot \mathrm{plant}^{-1} \cdot \mathrm{cm}^{-1}\right)$ & $0.94 \mathrm{~A}$ & $0.90 \mathrm{~A}$ & $0.85 \mathrm{~A}$ & $0.97 \mathrm{~A}$ & $0.90 \mathrm{~A}$ & $0.89 \mathrm{~A}$ \\
\hline
\end{tabular}

Average values followed by the same letter in the row do not differ from each other by the Scott-Knott at 5\% probability. SGT-Standard germination test; FC-First count; AA-Accelerated aging; EC-Electrical conductivity; SL-Seedling length; DM-Dry mass and BD-Biomass density.

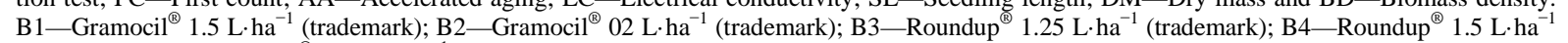
(trademark); B5-Roundup ${ }^{\circledR} 1.875 \mathrm{~L}^{\circ} \mathrm{ha}^{-1}$ (trademark) and B6-No application. 
translocation of the product to the interior of the seeds is limited. In turn, herbicides that have easier translocation than contact ones can cause further damage to the seeds, especially in phonological stages before harvesting time [21] [22].

According to [23], glyphosate is a systemic-action herbicide that rapidly translocates when applied to the leaves and pods. But according to [24], negative effects are not expected on seed quality with glyphosate desiccation at the physiological maturity stage, since the translocation of photo-assimilates from the plant to the seed is almost nil. However, [13] obtained negative results in the germination of soybean after aging, under glyphosate dissection test, justified as occurrence of local absorption of the glyphosate sprayed onto the pods, besides further degradation of molecules and formation of secondary metabolites.

Although some difference of up to $19.5 \%$ occurred in the first count between treatments, there was no significant difference between the averages of this variable. The non-application of desiccant and applications in B3 (Round Up-1.25 L·ha ${ }^{-1}$ ), B1 (Gramocil-1.5 L·ha ${ }^{-1}$ ) and B2 (Gramocil-2.0 L·ha ${ }^{-1}$ ) resulted in higher AA values, with averages of $87.5 \%$; $88.5 \%$; $79.5 \%$ and $80.5 \%$, respectively. On the other hand, B5 (Round Up$1.875 \mathrm{~L} \cdot \mathrm{ha}^{-1}$ ) resulted in the lowest average AA value (69.5\%). According to [21], in soybean desiccation test, weakening was observed in germination power and seedling vigor, using glyphosate and glufosinate ammonium herbicides.

Corroborating [19], the treatment with glyphosate has been shown to be harmful, resulting in the lowest vigor values. The same authors also found that the most dramatic effect on seeds occurred when desiccation was carried out with a greater dose of glyphosate (1.140 g i.a. ha $\left.{ }^{-1}\right)$.

In desiccation with glyphosate, negative effect is observed on the pigeonpea seed germination when they are submitted to accelerated aging, showing that an increase in the product dosage causes a reduction in aging values. [13] concluded that glyphosate desiccation of soybean in pre-harvest reduces seed germination and early seedling development. These authors also found that paraquat desiccation showed the lowest percentage of abnormal seedlings than treatments with glyphosate and glufosinate ammonium.

The seed quality evaluated by EC testing is inversely proportional to the obtained values, i.e. the higher the EC value, the more poorly structured the membranes are, reducing their physiological quality. Thus, it can be considered that in B5 (Round Up-1.875 L·ha ${ }^{-1}$ ) and B2 (Gramocil-2.0 L·ha ${ }^{-1}$ ) the treatment was harmful to the seeds compared to the others, with average EC values of $72.7 \mu \mathrm{S} \cdot \mathrm{cm}^{-1} \cdot \mathrm{g}^{-1}$ and $64.6 \mu \mathrm{S} \cdot \mathrm{cm}^{-1} \cdot \mathrm{g}^{-1}$, respectively. [25], in a study of seeds and conductivity observed better results in germination and vigor with electrical conductivity below $60 \mu \mathrm{S} \cdot \mathrm{cm}^{-1} \cdot \mathrm{g}^{-1}$, as with this study, where lower germination and vigor were found with higher doses of glyphosate (B5). [26] observed that paraquat desiccation of soybean in phonological stage at R6.0, R7.1 and R7.2 showed the highest electrical conductivity values.

Although no significant influence was detected, SL ranged from $7.8-9.3 \mathrm{~cm}$; DM ranged from $7.1-7.8$ $\mathrm{mg} \cdot$ plant $^{-1}$; and BD ranged from $0.85-0.97 \mathrm{mg} \cdot$ plant $^{-1} \cdot \mathrm{cm}^{-1}$ for all treatments studied. Non-significant results for seedling length support those obtained by [27], with bean seeds at different stages of desiccation. [28] [29] achieved the same result for radicle length at the different soybean desiccation stages studied.

In relation to seedling dry mass, the non-occurrence of differences between the control is quite interesting to the study because, according to [16], this method allows for precision evaluation of the transfer of dry mass from reserve tissues to the embryo, and more vigorous batches are those with the highest seedling dry mass (seedling ${ }^{-1} \cdot \mathrm{mg}$ ).

\section{Conclusions}

The application of Round Up-1.875 L·ha ${ }^{-1}$ was harmful to the viability and accelerated aging of pigeonpea seeds.

The applications of Round Up-1.875 L·ha ${ }^{-1}$ and Gramocil $-2.0 \mathrm{~L} \cdot \mathrm{ha}^{-1}$ resulted in higher values for pigeonpea seed electrical conductivity.

The vigor of pigeonpea seeds as measured by the first count, seedling length, seedling dry mass and biomass density tests was not affected by the type of desiccant applied during production.

\section{Acknowledgements}

To the Foundation for Support of Higher Education-CAPES the partial funding of research and the receive of the scholarship to the first author. The National Council for Scientific and Technological Development-CNPq 
the receive of productivity in research grants to the second and sixth author.

\section{References}

[1] Fuller, D.Q. and Harvey, E.L. (2006) The Archeobotany of Indian Pulses: Identification, Processing and Evidence for Cultivation. Environmental Archeology, 11, 219-246. http://dx.doi.org/10.1179/174963106x123232

[2] Sharma, S., Agarwal, N. and Verma, P. (2011) Pigeonpea (Cajanus cajan L.): A Hidden Treasure of Regime Nutrition. Journal of Functional and Environmental Botany, 1, 91-101. http://dx.doi.org/10.5958/j.2231-1742.1.2.010

[3] Varshney, R.K., Penmetsa, R.V., Dutta, S., Kulwl, P.L., Saxena, R.K., Datta, S., Sharma, T.R., Rosen, B., Carrasquilla-Garcia, N., Farmer, A.D., Dubey, A., Saxena, K.B., Gao, J., Fakrudin, B., Singh, M.N., Singh, B.P., Wanjari, K.B., Yuan, M., Srivstava, R.K., Kilian, A., Upadhyaya, H.D., Mallikarjuna, N., Town, C.D., Bruening, G.E., HE, G., May, G.D., Mccombie, R., Jackson, S.A., Sngh, N.K. and Cook, D.R. (2010) Pigeonpea Genomics Initiative (PGI): An International Effort to Improve Crop Productivity of Pingeonpea (Cajanus cajan L.). Molecular Breeding, 26, 393-408. http://dx.doi.org/10.1007/s11032-009-9327-2

[4] Saxena, K.B., Kumar, R.V. and Sultana, R. (2010) Quality Nutrition through Pigeonpea—A Review. Health, 2, 13351344. http://dx.doi.org/10.4236/health.2010.211199

[5] Mukherjee, D. and Ponmeni, G. (2004) Effect of Kineti on the Regulation of Abscission and Senescence in Pigeon Pea. Physiology and Molecular Biology of Plants, 10, 223-231.

[6] Upadhyaya, H.D., Reddy, K.N., Gowda, C.L.L. and Singh, S. (2010) Identification and Evaluation of Vegetable Type Pigeonpea (Cajanus cajan (L.) Millsp.) in the World Germplasm Collection at ICRISAT Genebank. Plant Genetic Resources, 8, 162-170. http://dx.doi.org/10.1017/S1479262110000122

[7] Bonner, F.T. (2008) Storage of Seeds. The Woody Plant Seed Manual. Agriculture Handbook 727. Department of Agricultural, Missisipi, 86-95.

[8] Wang, L., Ma, H., Song, L., Shu, Y. and Gu, W. (2012) Comparative Proteomics Analysis Reveals the Mechanism of Pre-Harvest Seed Deterioration of Soybean under High Temperature and Humidity Stress. Journal of Proteomics, 75, 2109-2127. http://dx.doi.org/10.1016/j.jprot.2012.01.007

[9] Lima, L.K., Ramalho, M.A.P. and Abreu, A.F.B. (2013) Selection of Common Bean Inbred Lines with Tolerance to High Moisture at Harvest. Ciência e Agrotecnologia, 37, 152-158. http://dx.doi.org/10.1590/S1413-70542013000200006

[10] Silva, A.C. (2006) Dessecação pré-colheita de soja e Brachiaria brizantha consorciadas com doses reduzidas de graminicidas. Pesquisa Agropecuária Brasileira, 41, 37-42. http://dx.doi.org/10.1590/S0100-204X2006000100006

[11] Santos, J.B., Ferreira, E.A., Ferreira, E.M., Silva, A.A. and Ferreira, L.R. (2005) Efeitos da dessecação de plantas de feijão sobre a qualidade de sementes armazenadas. Planta Daninha, 23, 645-651. http://dx.doi.org/10.1590/S0100-83582005000400012

[12] Miguel, M.H. (2003) Herbicidas dessecantes: Momento de aplicação, eficiência e influência no rendimento na qualidade de sementes de feijão. Tese de doutorado, Universidade de São Paulo, Piracicaba.

[13] Toledo, M.Z., Castro, G.S.A., Crusciol, C.A.C., Soratto, R.P., Nakagawa, J. and Cavariani, C. (2011) Physiological Quality of Soybean and Wheat Seeds Produced with Alternative Potassium Sources. Revista Brasileira de Sementes, 33, 363-371. http://dx.doi.org/10.1590/S0101-31222011000200019

[14] BRASIL (2009) Regras para análises de sementes. Ministério da Agricultura Pecuária e Abastecimento, Brasília, 398.

[15] Marcos Filho, J. (2005) Fisiologia de sementes de plantas cultivadas. Fealq, Piracicaba, 291-348.

[16] Krzyzanowski, F.C., Vieira, R.D. and França Neto, J.B. (1999) Vigor de sementes: Conceitos e testes. Informativo Abrates, Londrina, 218.

[17] Pereira, W.A., Sávio, F.L., Borém, A. and Dias, D.C.F.S. (2009) Influência da disposição, número e tamanho das sementes no lote de comprimento de plântulas de soja. Revista Brasileira de Sementes, 31, 113-121. http://dx.doi.org/10.1590/S0101-31222009000100013

[18] Ferreira, D.F. (2011) Sisvar: A Computer Statistical Analysis System. Ciência e Agrotecnologia, 35, 1039-1042.

[19] Kamikoga, A.T.M., Kamikoga, M.K., Terasawa, J.M., Romanek, C. and Penkal, K.F. (2009) Efeito de diferentes épocas de aplicação de três herbicidas dessecantes da produção e qualidade fisiológicas de feijão. Ciência Agrícola e Engenharia, 15, 53-61.

[20] Ekmekci, Y. and Terzioglu, S. (2005) Effects of Oxidative Stress Induced by Paraquat on Wild and Cultivated Wheats. Pesticide Biochemistry and Physiology, 83, 69-81. http://dx.doi.org/10.1016/j.pestbp.2005.03.012

[21] Guimarães, V.F., Hollmann, M.J., Fioreze, S.L., Echer, M.M., Rodrigues-Costa, A.C.P. and Andreotti, M. (2012) Produtividade e qualidade de sementes de soja em função de estádios de dessecação e herbicidas. Planta Daninha, 30, 
567-573. http://dx.doi.org/10.1590/S0100-83582012000300012

[22] Lacerda, A.L.S., Lazarini, E., Sá, M.E. and Valério Filho, W.V. (2005) Efeitos da dessecação de plantas de soja no potencial fisiológico e sanitário das sementes. Bragantia, 64, 447-457. http://dx.doi.org/10.1590/S0006-87052005000300015

[23] Timossi, P.C., Durigan, J.C. and Leite, G.J. (2006) Eficácia de glyphosate em plantas de cobertura. Planta Daninha, 24, 475-480. http://dx.doi.org/10.1590/S0100-83582006000300008

[24] Carvalho, N.M. and Nakagawa, J. (2000) Sementes: Ciência tecnologia e produção. 4th Edition, Fundação Cargill, Campinas, 588.

[25] Sá, M.E. and Lazarini, E. (1995) Relação entre os valores de condutividade elétrica e níveis de emergência em sementes de diferentes genótipos de soja. Informativo Abrates, 5, 143.

[26] Kappes, C., Carvalho, M.A.C. and Yamashita, O.M. (2009) Potencial fisiológico de sementes de soja dessecadas com diquat e paraquat. Scientia Agraria, 10, 1-6. http://dx.doi.org/10.5380/rsa.v10i1.12520

[27] Kappes, C., Arf, O., Ferreira, J.P., Portugal, J.R., Alcalde, A.M., Arf, M.V. and Vilela, R.G. (2012) Qualidade fisiológica de sementes e crescimento de plântulas de feijoeiro, em função de aplicações de paraquat em pré-colheita. Pesquisa Agropecuária Tropical, 42, 9-18. http://dx.doi.org/10.1590/S1983-40632012000100002

[28] Daltro, E.M.F., Albuquerque, M.C.F., França Neto, J.B., Guimarães, S.C., Gazziero, D.L. and Henning, A.A. (2010) Aplicação de dessecantes em pré-colheita: Efeito na qualidade fisiológica de sementes de soja. Revista Brasileira de Sementes, 32, 111-122. http://dx.doi.org/10.1590/S0101-31222010000100013

[29] Malaspina, I.G. (2008) Épocas de aplicação de dessecantes na cultura da soja (Glycine max (L.) Merrill): Teor de água, produtividade e qualidade fisiológica das sementes. Ph.D. Dissertação, Universidade Estadual de São Paulo, São Paulo. 